\title{
TEST GNSS PŘÍIJÍMAČE S INERCIÁLNÍM SKLONOMĚREM \\ A FOTOGRAMMETRICKOU KAMEROU LEICA GS18 I
}

\section{TEST OF THE GNSS RECEIVER WITH INERTIAL INCLINOMETER} AND PHOTOGRAMMETRIC CAMERA LEICA GS18 I

\section{Daniel Šantora ${ }^{1}$}

\begin{abstract}
Abstrakt
V tomto příspěvku Vám přinášíme podrobné informace o výsledcích našeho rozsáhlého testu přesnosti měření souřadnic bodů ze snímků z integrované kamery GNSS přijímače Leica GS18 I.
\end{abstract}

\section{Abstract}

In this paper, we present detailed information of our extensive test of the accuracy of point coordinates using images from the integrated GNSS camera of the Leica GS18 I receiver.

\section{Klíčová slova}

GNSS, GS18 I, Leica Geosystems, GEFOS

\section{Keywords}

GNSS, GS18 I, Leica Geosystems, GEFOS

\section{1 Úvod}

V tomto příspěvku Vám přinášíme podrobné informace o výsledcích našeho rozsáhlého testu přesnosti měření souřadnic bodů ze snímků z integrované kamery GNSS přijímače Leica GS18 I.

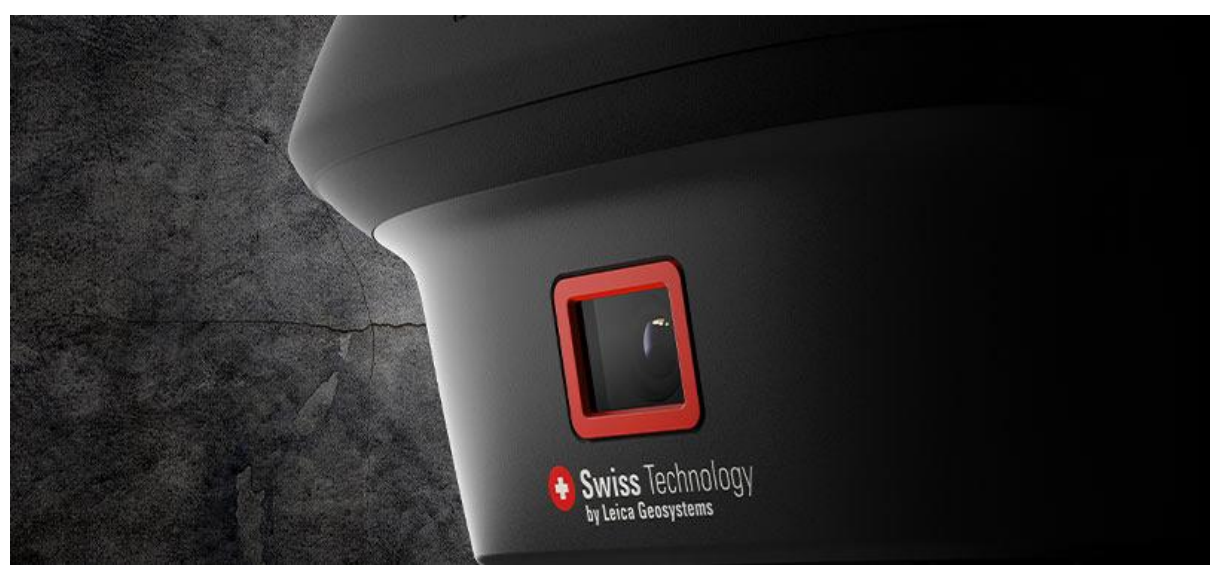

\footnotetext{
${ }^{1}$ Daniel Šantora, Ing., GEFOS a.s., zastoupení Leica Geosystems pro ČR, Kundratka 17, 18082 Praha 8, tel.: 284007 034, e-mail: daniel.santora@gefos.cz
} 


\section{Funkce GS18I - stručná rekapitulace}

Leica GS18 I je kompaktní GNSS přijímač se sklonoměrnou inerciální jednotkou (IMU) a fotogrammetrickou kamerou. Díky přesné RTK pozici a náklonům z IMU jsou pro kameru známé prvky vnější orientace, takže měřením na překrytových oblastech snímků je možné určovat 3D souřadnice. Pořizování snímků probíhá za chůze automaticky v rámci tzv. skupin snímků. Kamera musí být natočena kolmo ke směru chůze k oblasti, ve které chceme určovat souřadnice bodů. Určované body musí být ve vzdálenosti $2-10 \mathrm{~m}$ od prístroje, aby platila specifikace přesnosti určovaných bodů $2-4 \mathrm{~cm}$. Trajektorie chůze kolem zájmové oblasti by měla být zakřivena do oblouku se středem ve směru oblasti zájmu.

Měření souřadnic ze snímků pak probíhá přímo v polním softwaru Leica Captivate (v kontroleru, prŕípadně $\mathrm{v}$ simulátoru) nebo $\mathrm{v}$ kanceláŕském softwaru Leica Infinity, kde lze ze snímků navíc generovat i 3D mračna bodů.

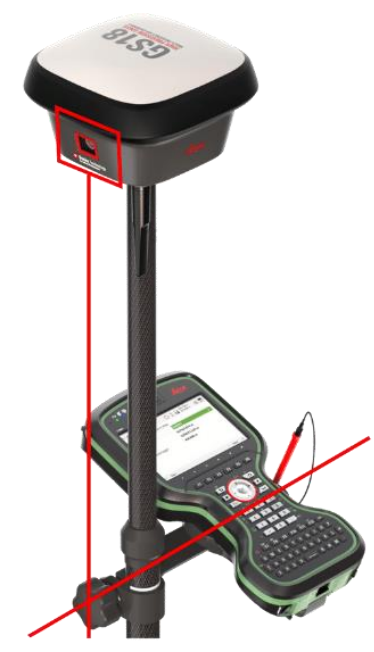

GS18 I je vylepšenou verzí stávajícího senzoru GS18 T a umožňuje kromě nově zavedeného fotogrammetrického určování bodů i oblíbené měření bodů s nakloněnou tyčkou, kdy pomocí přesného určení náklonů prostřednictvím IMU a známé délce tyčky dochází k př̀počtu přesné pozice na hrot nakloněné tyčky.

\section{Popis testu přesnosti}

Testování bylo prováděno př́strojem Leica GS18 I ve verzi Unlimited (všechny GNSS multifrekvenční signály) se softwarem Leica Captivate verze 5.50 a v kombinaci s polním kontrolerem CS20 LTE se softwarem Leica Captivate téže verze. Pro přesné svazkové vyrovnání fotografií, práci s mračnem a další výpočty byl použit kancelářský software Leica Infinity verze 3.4.1. Ve všech př́padech se jedná o první verze softwaru umožňující využití této naprosto nové a převratné technologie.

\subsection{Lokalita a testovací body}

Bylo vytvořeno 5 testovacích bodů, které byly rozmístěny těsně nad podezdívkou tuhého železného plotu v lokalitě Kundratka u sídla firmy GEFOS a.s. Pro přesnou identifikaci na snímcích byly body signalizovány kruhovými šachovnicovými terči o průměru 4,5 “ $(11,4 \mathrm{~cm})$.

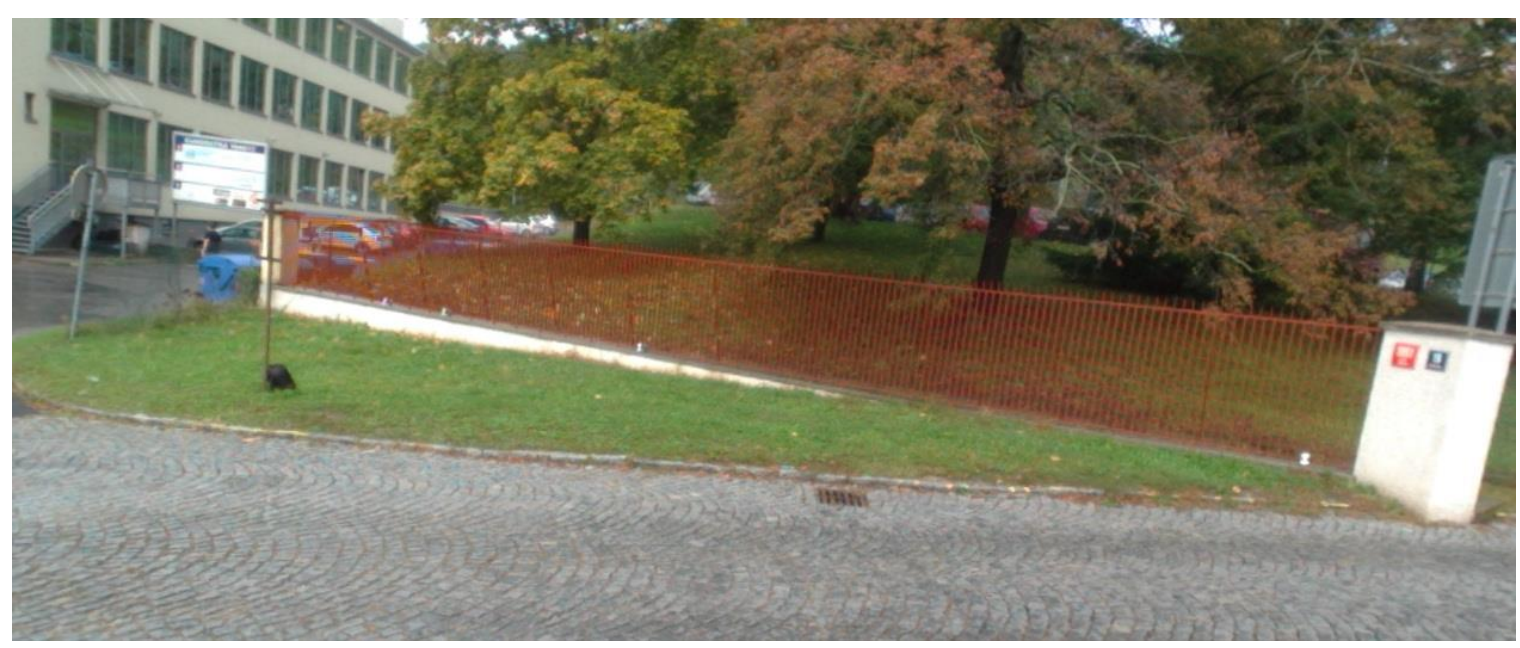




\subsection{GNSS měření}

Pro získání výchozích souřadnic bodů byly terče zaměřeny pomocí hrotu nakloněné tyčky přístrojem GS18 I metodou RTK s připojením k síti CZEPOS a s využitím čtyř GNSS systémů GPS, GLONASS, Galileo a BeiDou. Měrení bylo provedeno několikrát před a po snímkování. Výjimkou je bod č. 1, který byl záhy zrušen pro nevhodné umístění a nahrazen bodem č. 5 .

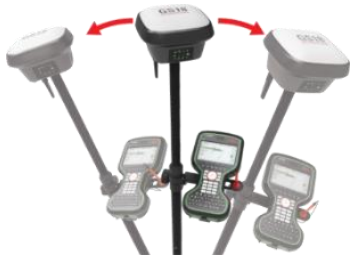

\subsection{Snímkování}

Jedním z hlavních cílů tohoto testu bylo podchytit vliv vzdálenosti př́stroje od určovaných bodů na přesnost těchto bodů. Vzhledem ke kritériu daným výrobcem, že určované body musí být ve vzdálenosti od přístroje 2 až $10 \mathrm{~m}$, byly zvoleny skupiny snímků, tj. jednotlivé průchody v přibližných vzdálenostech od bodů:

- po dvou průchodech ve vzdálenostech $2 \mathrm{~m}, 5 \mathrm{~m}$ a $10 \mathrm{~m}$. Ve $2 \mathrm{~m}$ byly navíc provedeny dva velmi krátké průchody kolem jednotlivých bodů.

- po jednom průchodu ve vzdálenosti 15 m a 20 m, aby se zjistilo, k čemu dojde při nedodržení vzdálenostního kritéria pro snímkování.

Znovu zdůrazňuji, že se jedná o vzdálenosti velmi přibližné, a to hlavně z důvodu podmínky, že trajektorie chůze musí být zakřivena do oblouku. Trajektorie jsou znázorněny pomocí kancelářského softwaru Leica Infinity na následujícím obrázku:

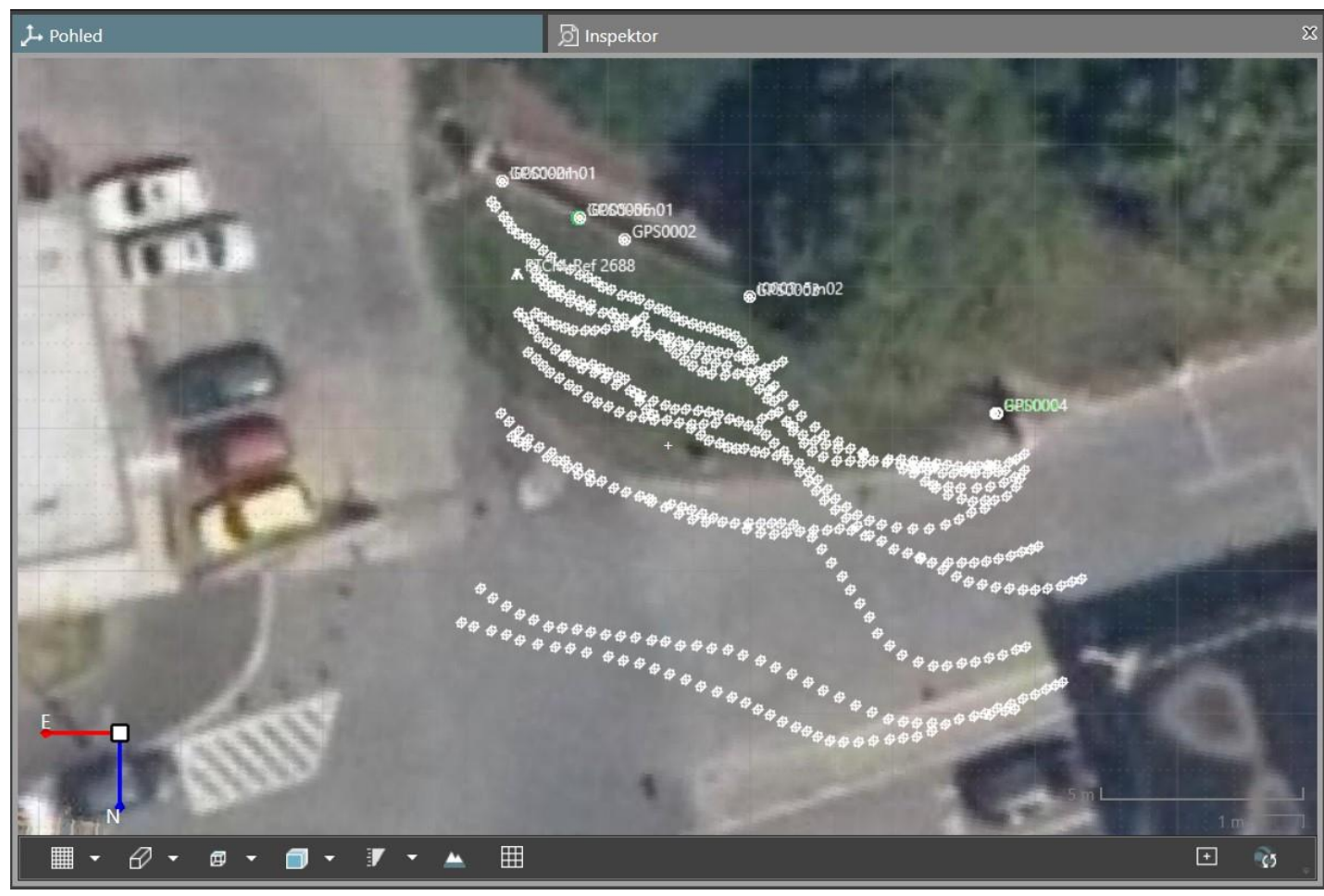

\subsection{Měření na snímcích v Leica Captivate}

Polní software Leica Captivate umožňuje měřit souřadnice bodů ze snímků v kontroleru a je úplně jedno, zda se to provede podle potřeby okamžitě nebo až v klidu v kanceláři. Za zmínku také stojí možnost odsouvání souřadnic v PC simulátoru Leica Captivate, kde je tato funkce uvolněna bez nutnosti zvláštní licence. Měření probíhá vždy v rámci jednotlivých skupin snímků tak, že se klikne ve snímku na bod a software sám v rámci možností určí stejné místo 
na okolních max. 5-ti snímcích. Za ideálních podmínek automat provede měření ne na sousedních snímcích, ale ob snímek, aby bylo docíleno delších fotogrammetrických základen a vhodnějších úhlů protnutí paprsků na bodech. Operátor se následně může rozhodnout, zda přidá observace na další snímky, kde je určovaný bod také dobře vidět, což v prŕípadě tohoto testu bylo prováděno, takže často jsou body určovány přibližně z 20-ti a více snímků. Na následujícím obrázku je prostředí Leica Captivate pro měření bodů ze snímků:

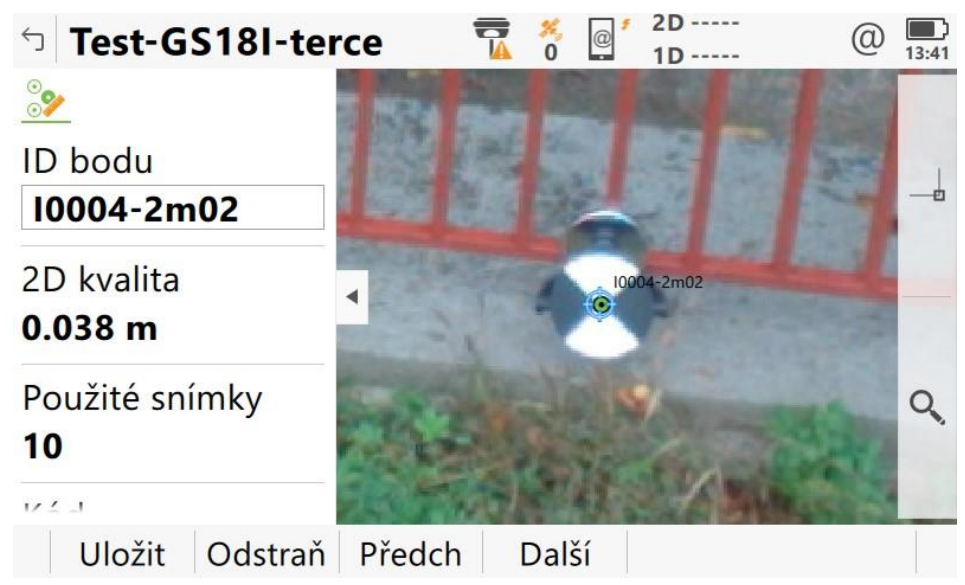

\subsection{Infinity - pohodlnější měření na snímcích}

Leica Infinity je modulární geodetický software na podporu měření moderními př́ístroji Leica. V případě licencí Základ + Základní Imaging je možné v Infinity provádět měření na snímcích mnohem pohodlněji než v polním softwaru. V př́ípadě tohoto testu však byl využit $\mathrm{i}$ další licenční modul „Pokročilý Imaging a tvorba 3D mračen, modelů povrchů a ortofot ze snímků“, který má mnohem více možností popsaných v následujících kapitolách. Mj. tento pokročilý modul byl původně vyvinut pro kompletní zpracování snímkových letů z dronů a následně v aktuální verzi 3.4.1 (ne starší!) optimalizován i pro zpracování snímkových skupin z GS18 I.

\subsection{Infinity - orientace snímků}

V případě, že máme pořízeno více skupin snímků s GS18 I, z nichž některé snímají stejnou oblast nebo alespoň významnou překrytovou část, lze v Infinity tyto skupiny vzájemně sloučit do jedné společné skupiny a provést novou orientaci, čili kompletní svazkové vyrovnání. To je př́pad tohoto testu, kde mnoho skupin snímá stále jeden a ten samý prostor, což není v praxi úplně typické. Při svazkovém převyrovnání v programu Infinity se to projevilo velmi dlouhou dobou zpracování, cca 4 hodiny strojového času. Výsledkem ovšem bylo, že se naprosto zásadně zmenšily odchylky měření na snímcích z této společné nově vyrovnané skupiny. Za normálních okolností v př́íp. dvou krátkých sloučených skupin trvá tento processing cca 2-3 minuty.

Důležité je také to, že toto zlepšení přesnosti se netýká jen bodů odsunutých ze snímků v Infinity, ale i těch, které byly původně měřeny v Captivate a spolu se snímky naimportovány do projektu Infinity. U takto změřených bodů se neimportují jen výsledné geodetické souřadnice, ale i souřadnice snímkové, a to umožňuje přepočet nových geodetických souřadnic z lépe orientovaných snímků.

Na následujícím obrázku je velmi přehledné intuitivní prostředí Leica Infinity pro měření bodů ze snímků: 


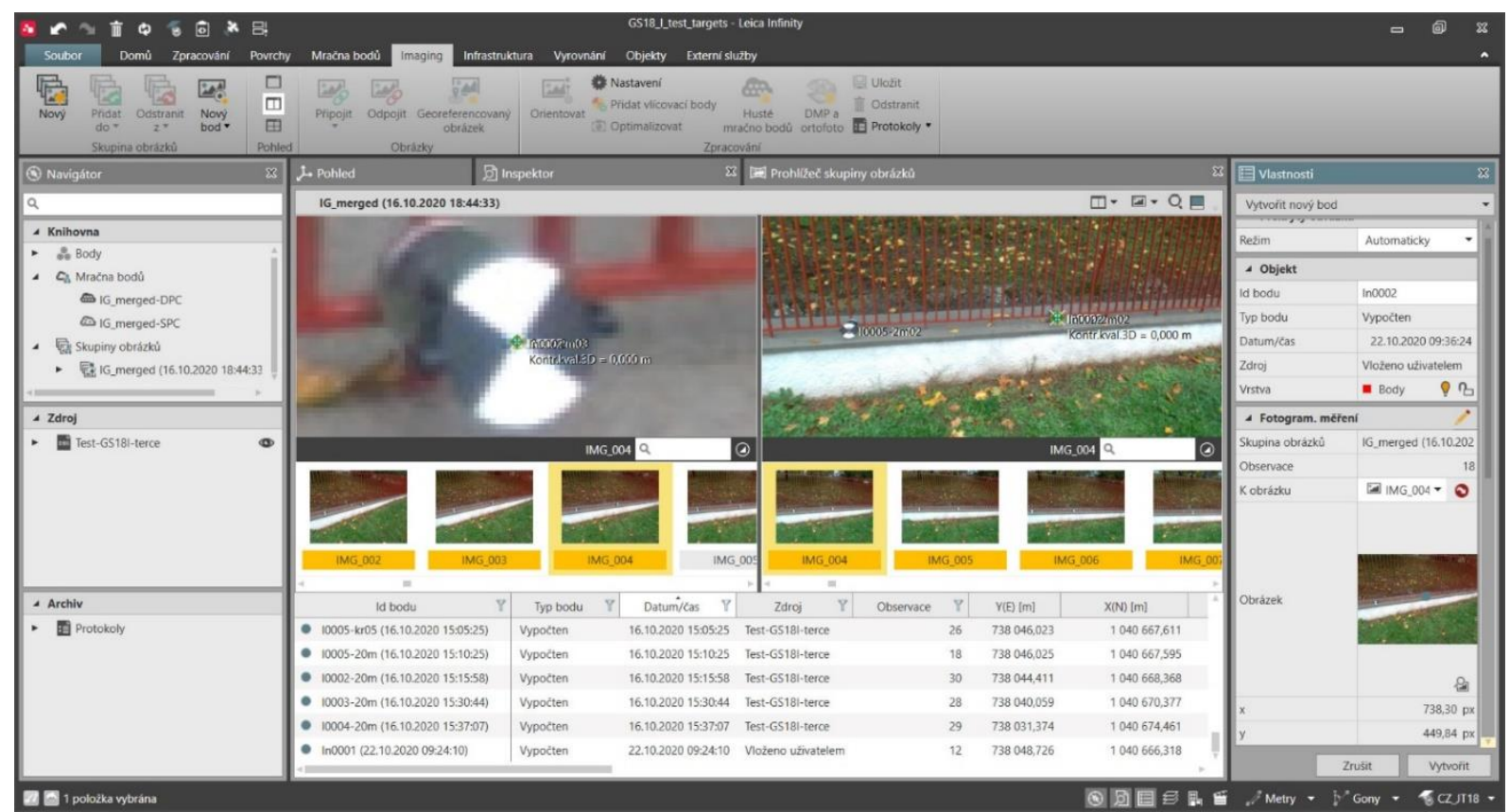

Takto bylo změřeno všech pět testovacích bodů, každý z cca 30 - 50 snímků v rámci sloučené velké skupiny snímků.

\subsection{Infinity - tvorba mračen bodů ze snímků}

Je-li v Infinity spočítána orientace, je možné ze skupiny snímků spočítat 3D mračno bodů metodou "Dense Image Matching“, stejně jako je to obvyklé při tvorbě modelů a ortofot z leteckých snímků. Zde se opět projevila ona netypická extrémní situace, kdy přes 500 snímků snímá jeden nevelký prostor, což poskytuje mnoho společných překrytů na velkém počtu snímkủ, a to se opět projevilo na čase potřebného k vygenerování mračna bodů, jež zabralo 9,5 h pro plné rozlišení mračna. V běžné praxi při dvou sloučených krátkých skupinách bude processing trvat cca 15-20 minut. Nicméně proces byl úspěšně dokončen a na následujícím obrázku je sejmutá obrazovka z Infinity s mračnem bodů:

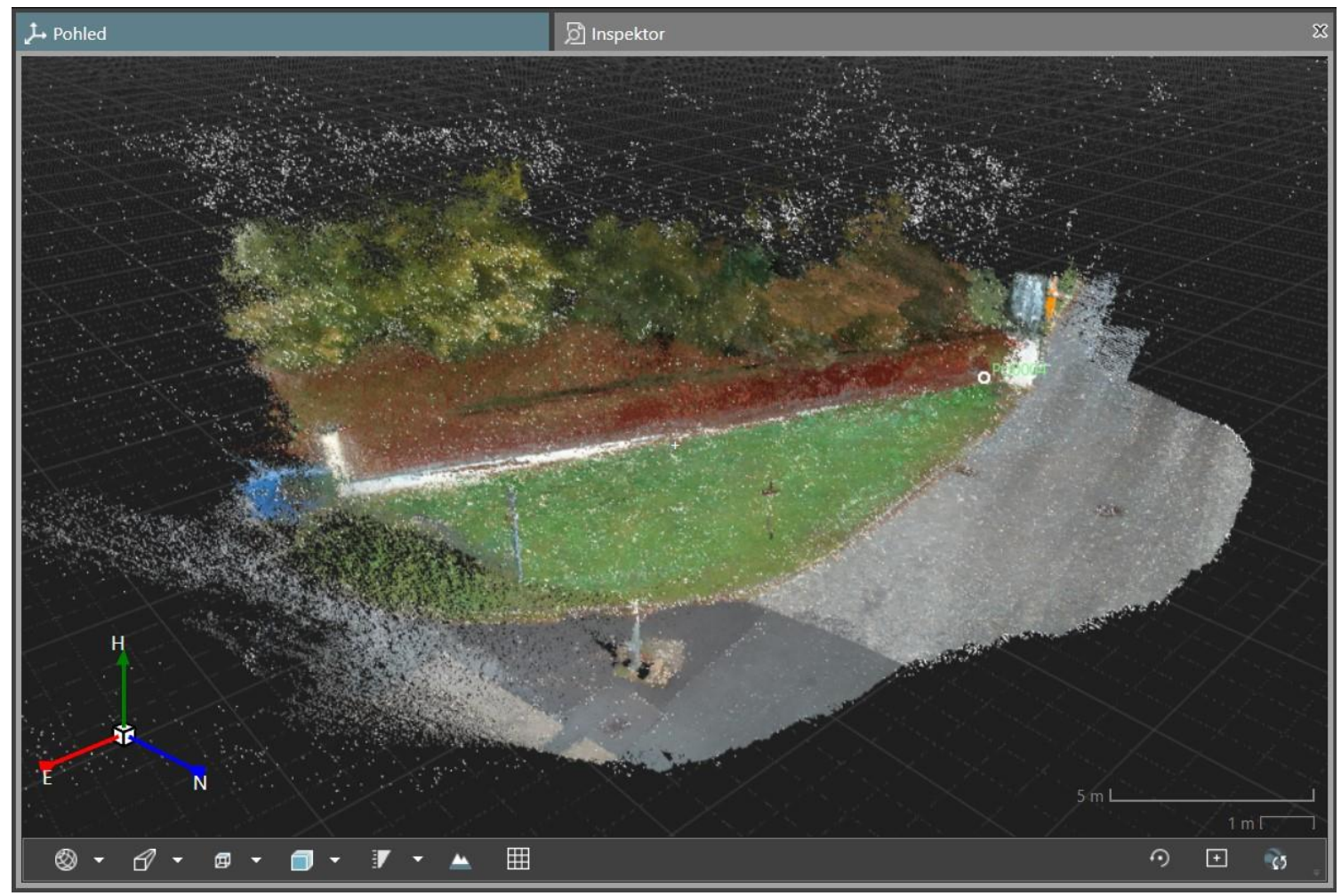


V Infinity lze následně z 3D mračen bodů manuálně odsouvat jednoduchým klikáním do mračna nové měřené objekty - body, line a plochy. Takto bylo také kontrolně změřeno všech pět testovacích bodů:

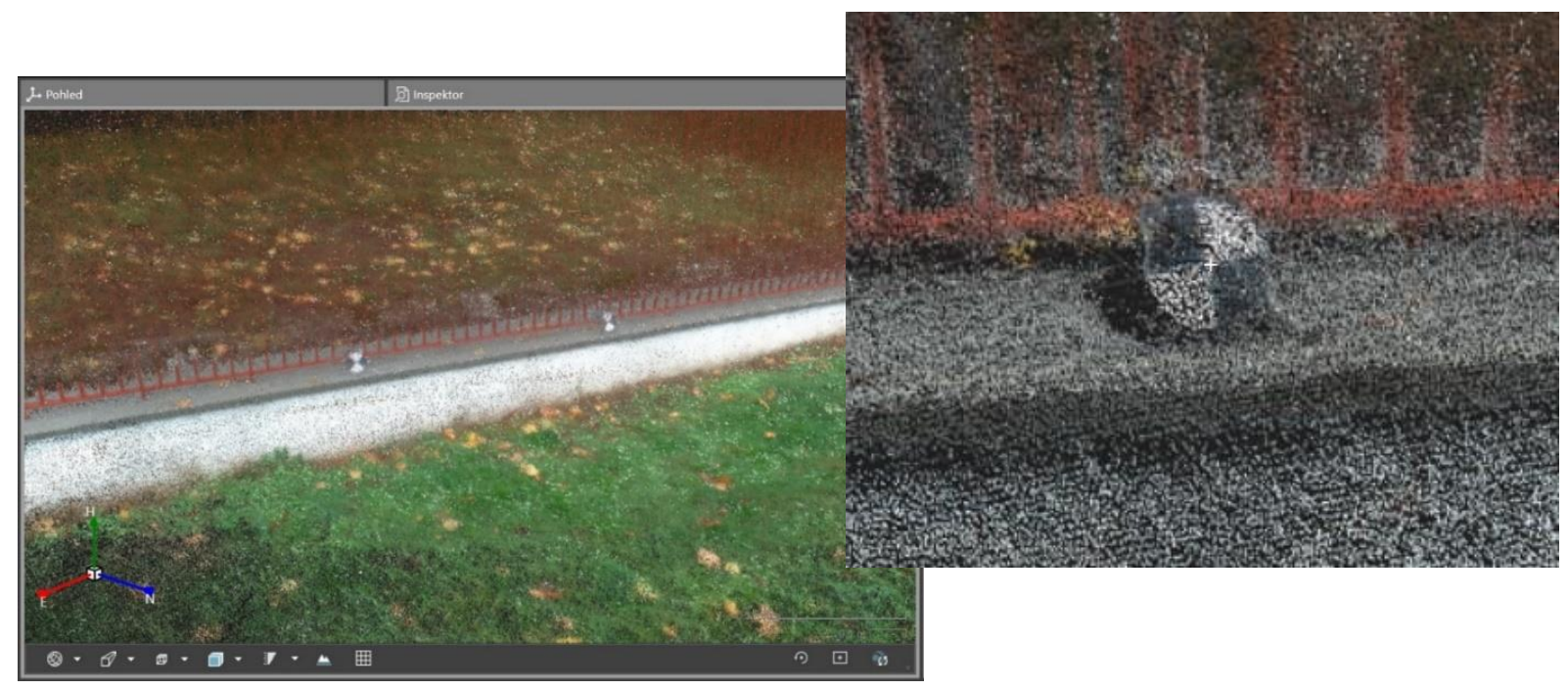

\section{Závěrečné vyhodnocení testu}

\subsection{Vyhodnocení přesnosti}

Tab. 1 Shrnutí přesnosti všech posuzovaných metod.

\begin{tabular}{|c|c|c|c|c|c|}
\hline Vzdálenost bodů & Zdroj výp. souř. & $\overline{\sigma \Delta p}$ & $\overline{\varnothing \Delta H}$ & $\max . \Delta p$ & $\max . \Delta H$ \\
\hline \multirow{2}{*}{$2 \mathrm{~m}$} & $\overline{\text { Captivate }}$ & $\overline{\mathbf{0 , 0 2 9}}$ & $\overline{\mathbf{0 , 0 2 2}}$ & 0,110 & (0,071 \\
\hline & Infinity & 0,011 & 0,013 & 0,017 & 0,039 \\
\hline \multirow{2}{*}{$5 \mathrm{~m}$} & Captivate & $\mathbf{0 , 0 3 1}$ & $\mathbf{0 , 0 2 2}$ & 0,042 & 0,067 \\
\hline & Infinity & 0,011 & 0,013 & 0,013 & 0,034 \\
\hline \multirow{2}{*}{$10 \mathrm{~m}$} & Captivate & 0,094 & 0,025 & 0,176 & 0,074 \\
\hline & Infinity & 0,013 & 0,013 & 0,017 & 0,035 \\
\hline \multirow{2}{*}{$15 \mathrm{~m}$} & Captivate & 0,092 & 0,021 & 0,113 & 0,064 \\
\hline & Infinity & 0,017 & 0,015 & 0,021 & 0,035 \\
\hline \multirow{2}{*}{$20 \mathrm{~m}$} & Captivate & 0,166 & 0,057 & 0,226 & 0,076 \\
\hline & Infinity & 0,022 & 0,019 & 0,028 & 0,036 \\
\hline Měření na snímcích v Infinity & Infinity & $\overline{0,010}$ & 0,012 & 0,013 & 0,034 \\
\hline $\begin{array}{l}\text { Identifikace v mračně v } \\
\text { Infinity }\end{array}$ & Infinity & 0,010 & 0,014 & 0,010 & 0,036 \\
\hline
\end{tabular}

Poznámky k Tab. 1:

- Vzdálenost bodů: přibližná průměrná vzdálenost př́istroje od určovaných bodů během průchodů při pořizování skupin snímků. Tato vzdálenost významně kolísá vzhledem $\mathrm{k}$ požadavku na průchod po zakřivené trajektorii. 
- Zdroj výpočtu souřadnic:

- Captivate: Souřadnice získané ihned po odsunutí ze snímků v polním softwaru Leica Capticate, tj. z jednotlivých nasbíraných skupin bez jejich společného převyrovnání $\mathrm{v}$ Leica Infinity.

○ Infinity: U bodů měřených v polním softwaru Captivate se jedná o souřadnice po vyrovnání jedné společné skupiny snímků, do které byly zahrnuty všechny pořízené skupiny snímků, prrípadně se jedná o měření př́ímo na snímcích či v mračnu v programu Leica Infinity po vyrovnání skupin snímků.

- $\quad \boldsymbol{\Delta \Delta}, \boldsymbol{\phi} \Delta \mathbf{H}$ : Průměrné odchylky od průměru GNSS měření.

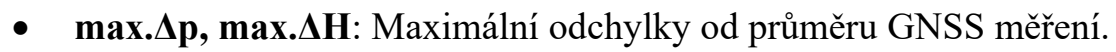

Z Tab. 1 vyplývá, že pokud budeme chtít měřit body s polohovou přsesností do $4 \mathrm{~cm}$ ze skupin snímků pořízených s GS18 I, měli bychom se s přístrojem pohybovat od $2 \mathrm{~m}$ do cca 7-8 $\mathrm{m}$ od určovaných bodů. Výrobce udává vzdálenost do $10 \mathrm{~m}$, ovšem při požadavku na zakřivenou trajektorii je pohyb na hranici $10 \mathrm{~m}$ značně rizikový, protože tato vzdálenost se již těžko odhaduje a snadno překročí, $\mathrm{k}$ čemuž určitě došlo při průchodech označených $\mathrm{v}$ tabulce vzdáleností „10 m“. Maximální výrobcem udávané vzdálenosti $10 \mathrm{~m}$ lze tedy dle zjištění v rámci testování důvěřovat, ale je nutné ji považovat za limitní. Vzdálenosti $15 \mathrm{~m}$ a $20 \mathrm{~m}$ jsou daleko za kritérii, které uvádí výrobce pro sběr přesných dat, a byly pořízeny pouze pro zajímavost, co se v těchto př́ípadech děje s přesností pořízených dat.

Co se týče přesností v poloze a výšce, tak mnohem náchylnější na vznik chyb je při výpočtu v programu Leica Captivate poloha než výška. Nejspíše je to tím, že pro IMU jednotku je nejnáročnější úkol určení natočení přijímače kolem svislé osy.

Úplně jiná situace je po sloučení více skupin, které pokrývají stejné území, do jedné skupiny, u které se pak provede nové společné svazkové vyrovnání v programu Leica Infinity. Výsledkem je homogenní model, ve kterém již tolik nezáleží na tom, z jak vzdálených snímků se body odsouvají. Jediné, co zde ovlivňuje přesnost je, že ze vzdálených snímků se body hůře identifikují kvůli rozlišení snímků. Po společném vyrovnání je přesnost podstatně lepší, což je také patrné z tabulky. Ještě zopakuji, že dochází k zásadnímu zlepšení přesnosti i u fotogrammetricky měřených bodů v Leica Captivate, protože skrze snímkové souřadnice dochází k novému výpočtu geodetických souřadnic bodů z nového modelu po vyrovnání.

Následující tabulka graficky znázorňuje polohu jednotlivých měření v Leica Captivate. Vyplývá z ní, že větší chyby se vyskytují spíše na okrajích jednotlivých skupin snímků a navíc vykazují tendenci vyšších hodnot ve směru od př́istroje. Tento trend je vidět zejména u bodu č. 4. Uprostřed skupin snímků jsou chyby menší a mají více nahodilý charakter:

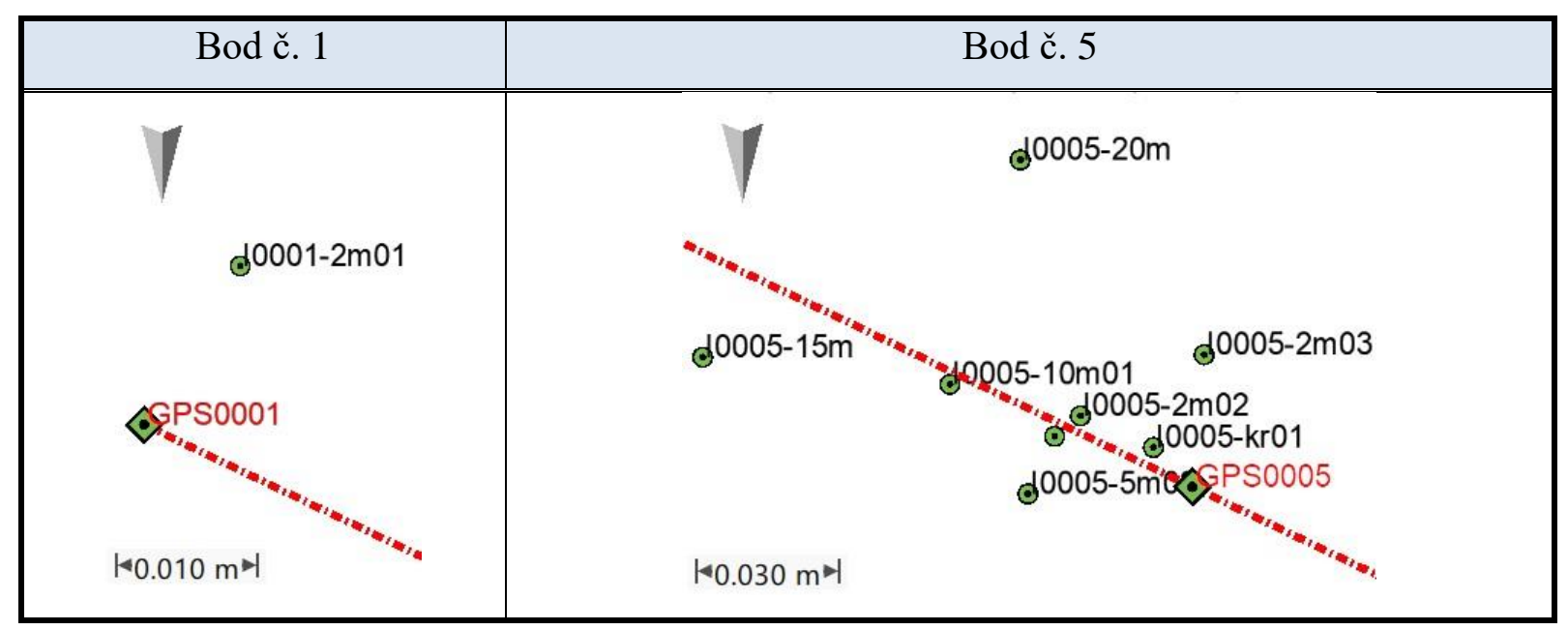




\begin{tabular}{|c|c|c|}
\hline Bod č. 2 & Bod č. 3 & Bod č. 4 \\
\hline 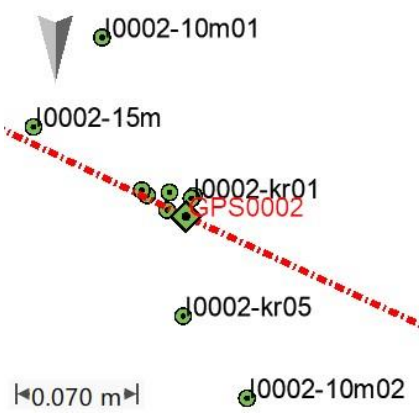 & 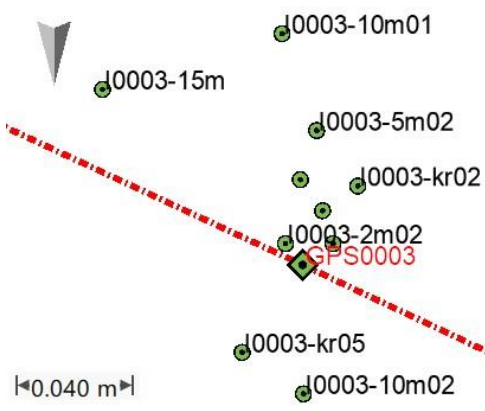 & 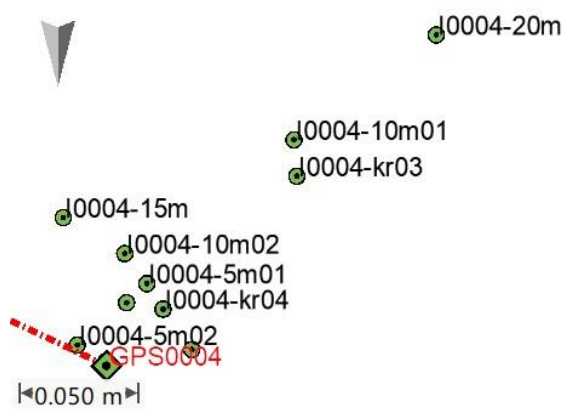 \\
\hline
\end{tabular}

\section{2 Časová náročnost}

Pro posouzení produktivity práce je nutné zmínit, jak je sběr skupin snímků a odsouvání souřadnic časově náročné.

Před snímkováním se v Captivate spouští aplikace GS snímky > Skupina snímků, kdy dochází $\mathrm{k}$ inicializaci kamery, což je otázka pár vteřin a provádí se během snímkování pouze jednou při vstupu do této aplikace. Pak je již možné stisknout tlačítko Start a rozejít se.

Časově nejnáročnější je proces ihned po ukončení každé skupiny snímků. Po stisku tlačítka Stop nebo po automatickém zastavení snímkování se automaticky rozbíhá proces, kdy Captivate na pozadí tvoří na významných kontrastech snímků spojovací body a na základě této poměrně velké množiny snímkových observací provádí svazkové vyrovnání. Pokud je vyrovnání úspěšné, což při zachování základních podmínek pro snímkován je pravidlem, tak se musí skupina snímků ještě uložit stiskem tlačítka „Ulož“. Čas potřebný pro tyto dvě operace vyrovnání + uložení závisí na délce skupiny snímků. Při použití kontroleru CS20 LTE se přibližně jedná o časy:

Tab. 2 Výpočetní časy v kontroleru Leica CS20 LTE.

\begin{tabular}{|l|l|}
\hline $\begin{array}{l}\text { Délka skupiny snímků } \\
\text { sekundách }\end{array}$ & Přibližný čas operací vyrovnání + uložení \\
\hline Do $15 \mathrm{~s}$ & $20 \mathrm{~s}$ \\
\hline Těsně pod $30 \mathrm{~s}$ & $40 \mathrm{~s}$ \\
\hline Nad $30 \mathrm{~s}$ & $2 \min 30 \mathrm{~s}$ \\
\hline $60 \mathrm{~s}$ & až $6 \mathrm{~min}$ \\
\hline
\end{tabular}

Z Tab. 2 je patrné, že čas pro vyrovnání skupiny snímků v kontroleru CS20 LTE skokově narůstá po $30 \mathrm{~s}$, tj. po 60-ti snímcích. Časově nejefektivnější je tedy sbírat skupiny snímků s délkou chůze do 30 sekund. Námi zjištěný doporučený časový interval pro snímkové skupiny je od $10 \mathrm{~s}$ do $30 \mathrm{~s}$. Dolní mez je stanovena vzhledem k již dříve zmíněnému rozložení chyb ve vodorovné poloze u př́liš krátkých skupin.

Dle informací zjištěných u výrobce jsou tyto procesní časy výrazně kratší při použití polního tabletu CS35. Ten však nebyl v tomto testu nasazen. 


\section{Ověřování a tvorba protokolů pro odevzdání výsledků do KN}

Měření s využitím kamery s Leica GS18 I je principiálně založeno na kombinaci dvou metod:

- GNSS s využitím IMU

- Průseková fotogrammetrie

Tvorba GNSS protokolů je již dlouho vyhláškou přesně definována. Ovšem specifikum snímkování s GS18 I je, že vykazované GNSS informace se nevztahují přímo k určovaným bodům, ale k ohniskům kamery v době pořízení každého snímku. GNSS protokol vytvořený přes formátovou masku v Leica Captivate pro předání výsledků měření na Katastrální úřady vypadá následovně:

Bod GNSS (trrída $\mathrm{PR}=$ průměr, $\mathrm{ME}=$ měření):

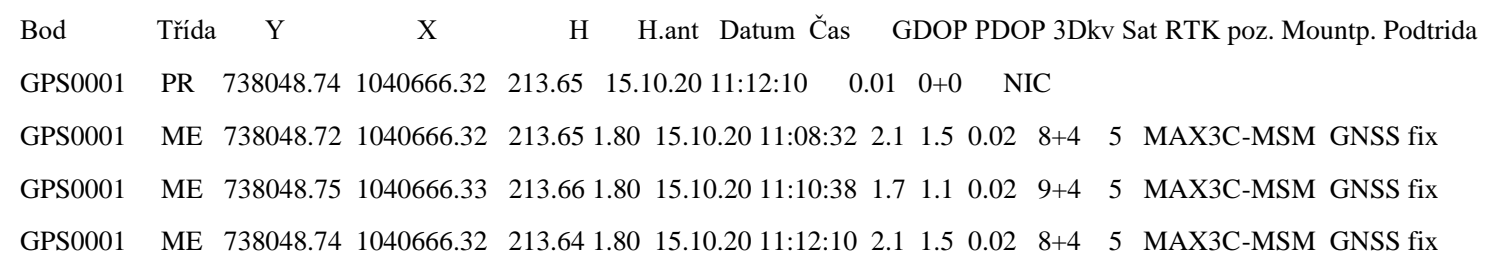

Bod ze snímků:

I0001-2m01 ME 738048.73 $1040666.31 \quad 213.62 \quad 15.10 .20$ 12:42:22 $\mathbf{0 . 0 2} \quad 0+0$ Imaging

U bodů ze snímků lze př́mo vykázat tyto relevantní informace: souřadnice, výšku, odhad kvality (střední chyby) a podtřídu, která má hodnotu „Imaging“, podle které se pozná, že byl bod určen měřením ze snímků. Chybí údaje o družicích a uvedený čas se týká doby odsunutí souřadnic ze snímku, nikoli času pořízení snímkové skupiny.

Je tedy třeba vykázat i pořízení jednotlivých skupin snímků. To lze prozatím v Leica Infinity po prrepočtu orientace:

\section{Informace o skupině obrázků}

$\begin{array}{llll}\text { Id skupiny obrázků: } & \text { IG-2m-1 (15.10.2020 11:19:42) } & \text { Senzor: } & \text { Leica Geosystems AG } \\ \text { Počet obrázků: } & 62 & \text { Model kamery: } & \text { AR0135 Camera } \\ \text { Šířka obrázku: } & 1280 \mathrm{px} & \text { EXIF ohnisková vzdálenost: } & 3,100 \mathrm{~mm} \\ \text { Výška obrázku: } & 960 \mathrm{px} & \text { Velikost pixelu: } & 0,004 \mathrm{~mm} \\ \text { Celková velikost obrázku: } & 0,08 \mathrm{Gpx} & \text { Průměrná velikost pixelu na 0,16 cm/px }\end{array}$

\section{Přehled výsledků}

Obecné

Orientovaná pozice kamery:

Medián spojovacích bodů na snímek:

Střední 3D chyba vlícovacích bodů:

Střední 3D chyba kontrolních bodů:

nMAD pro Control Points:

nMAD pro Check Points:

\section{Vnitřní orientace}

Zdroj kalibrace: Neznámý

\section{Tolerance kontrolních bodů}

62 / 62 Stř. chyba Y(E):

106 Stř. chyba $X(\mathrm{~N})$ :

- Stř. chyba horizontální:

- Stř. chyba výšky:

$-p x$

$-p x$ 
Konstanty kamery

\begin{tabular}{|c|c|c|c|}
\hline Parametr & $\begin{array}{c}\text { Počáteční } \\
\text { [mm] }\end{array}$ & $\begin{array}{c}\text { Kalibrováno } \\
\text { [mm] }\end{array}$ & $\begin{array}{c}\text { Rozdíl } \\
\text { [mm] }\end{array}$ \\
\hline Konstanta kamery $X$ & 3,149 & 3,153 & $-0,004$ \\
\hline Konstanta kamery $Y$ & 3,161 & 3,167 & $-0,006$ \\
\hline
\end{tabular}

\section{Hlavní bod}

\begin{tabular}{|c|c|c|c|}
\hline Parametr & Počáteční [px] & Kalibrováno [px] & Rozdíl [px] \\
\hline Hlavní bod X & 657,00 & 657,13 & $-0,13$ \\
\hline Hlavní bod Y & 468,00 & 468,37 & $-0,37$ \\
\hline
\end{tabular}

\section{Vnější orientace}

\section{Obecné informace}

$\begin{array}{lllll}\text { Celkový počet bodů 3D vazby: } & 16735 & \text { Průměrný počet spojovacích bodů na snímek: } & 104 \\ \text { Počet vlícovacích bodů: } & 0 & \text { Minimální počet spojovacích bodů na snímek: } & 64 \\ \text { Počet kontrolních bodů: } & 0 & \text { Maximální počet spojovacích bodů na snímek: } & 139 \\ \text { Střední chyba reprojekce spojovacích bodů: } & 0,96 \text { px } & & \end{array}$

Standardní odchylka absolutní pozice kamery

\begin{tabular}{|c|c|c|c|c|c|c|}
\hline Parametr & $\begin{array}{c}\mathbf{Y}(\mathbf{E}) \\
{[\mathbf{m}]}\end{array}$ & $\begin{array}{c}\mathbf{X}(\mathbf{N}) \\
{[\mathbf{m}]}\end{array}$ & $\begin{array}{c}\text { Orto.Výšky } \\
{[\mathbf{m}]}\end{array}$ & $\begin{array}{c}\text { Omega } \\
\text { [gon] }\end{array}$ & $\begin{array}{c}\text { Fí } \\
\text { [gon] }\end{array}$ & $\begin{array}{c}\text { Kappa } \\
\text { [gon] }\end{array}$ \\
\hline Průměr & 0,001 & 0,001 & 0,001 & 0,02080 & 0,05642 & 0,02905 \\
\hline Str̆.ch. & 0,000 & 0,000 & 0,000 & 0,00437 & 0,00575 & 0,00434 \\
\hline
\end{tabular}

Tento protokol je velmi rozsáhlý a orientovaný na fotogrammetrii. Pro budoucí použití pro katastr je do něj potřeba přidat GNSS údaje. Na tomto se již usilovně pracuje jak na komunikační lince GEFOS - Leica Geosystems, tak zjišt’ováním konkrétních požadavků od ČÚZK. Dosavadní legislativní „,vakuum“v této oblasti je způsobeno tím, že nejen pro Katastr nemovitostí se jedná o úplně novou metodu měření.

Po konzultacích s odborníky z ČÚZK a katastrálních úřadů dáváme dohromady požadavky na výrobce, aby speciálně pro náš trh vytvořil XSL styl pro export potřebných údajů rovnou z polního softwaru Leica Captivate.

Dále proběhla konzultace o možnostech ověřování bodů dvojím měřením tak, jak to stanoví vyhláška. Prozatím byly předběžně konzultovány dvě možnosti:

1) Projití dvou snímkových skupin s časovým odstupem, jak to stanoví vyhláška pro GNSS body s dvojím určením souřadnic bodů z těchto nezávislých skupin

2) Ověření skupiny snímků pomocí vybraných identických bodů určených ze snímků a zároveň GNSS měřením v jiném čase, čímž by se daná skupina prohlásila za správnou a použitelnou pro odsouvání bodů.

\section{Závěr}

GS18 I umožňuje zaměření nepř́stupných bodů přímo na kontroleru až do vzdálenosti $10 \mathrm{~m}$ $\mathrm{s}$ přesností, která vyhovuje požadavkům kladeným na podrobné body $\mathrm{v}$ katastru nemovitostí. Jako nejefektivnější se jeví pořizování skupin snímků v délce 15-30 sekund. Zpracování měření v Infinity vede $\mathrm{k}$ dalšímu zpřesnění pořízených dat a umožňuje i generování mračna bodů pro 
další vyhodnocení. Senzor GS18 I dále rozššřil možnosti využití a zvýšil produktivitu GNSS technologie.

\section{Literatura}

[1] Uživatelská príručka Leica GS18, Art.no. 931033-3.0.0cs-překlad z anglické uživatelské přiručky Leica GS18 Art.no. 851580-3.0.0en.

Daniel Šantora

GEFOS a.s.

Obchodní zastoupení Leica Geosystems pro ČR

Kundratka 17, 18082 Praha 8, Czech Republic

Web: http://www.gefos-leica.cz, http://www.leica-geosystems.com

Recenzováno: 25. 1. 2022 